\title{
Pawel Wójs*
}

Pedagogical University of Krakow

ORCID: 0000-0002-4708-1536

\section{EXISTENTIAL EXPERIENCE LIKE ILLNESS: A CASE STUDY OF GILBERT JONAS}

\begin{abstract}
The works of the philosophers of existence often address illness and health in the context of a (difficult to describe) existential experience. In this paper I will argue the following thesis: one of the strategies chosen by the authors whose aim is to characterise an existential experience is to present it by referring to the category of illness. This strategy involves, first and foremost, presenting the similarity between the existential experience and an illness; while at the same time, emphasising that the existential experience is not an illness (although of course, the existential experience may be a consequence of experiencing an illness). To support my basic thesis, I will draw from the works of Albert Camus, Lev Shestov and other philosophers of existence, as well as from literary works. In the article, I will provide an interpretation of Albert Camus' short story "Jonas, or the Artist at Work". I will discuss the basic characteristics of the existential experience, focusing on those that are similar to the symptoms of illness. I will also formulate a number of general remarks which concern the existential experience.
\end{abstract}

Keywords: illness, disorder, existential experience, existentialism, philosophy of existence

Studying the works of the philosophers of existence reveals that, in the context of analyses concerning the (very difficult to describe) existential experience (cf. Mounier 1964; Piecuch 2011; Warnock 2005; Wilson 1992; Wójs 2013), these works address issues concerning illness and health fairly frequently. The plight of the literary characters discussed by the philosophers of existence, ${ }^{1}$ as well as characters from their literary works, often experience a state that is sometimes interpreted as an illness. This primarily concerns mental illnesses, which are accompanied by symptoms such as behaviours that are incomprehensible (for the character himself or herself, and for the character's family and friends), sudden changes of lifestyle, panic attacks, outbursts of anger, despair, feelings of guilt, low mood, apathy, suicidal

* Corresponding author: Paweł Wójs, Uniwersytet Pedagogiczny, Instytut Filozofii i Socjologii, ul. Podchorążych 2, 30-084 Kraków; e-mail: pawelwojs@up.krakow.pl.

1 I discuss the issue of which philosophers should be considered as philosophers of existence in an earlier work (Wójs 2013: 24-40; 2017: 17-30). 
thoughts, depersonalisation and derealisation. They often also concern somatic illnesses that are accompanied by symptoms like fever, sweating, insomnia, lack of appetite, nausea, and pain.

In this paper I will argue the following thesis: one of the strategies chosen by the authors whose aim is to characterise an existential experience is to present it by referring to the category of illness. This strategy involves, first and foremost, presenting the similarity between the existential experience and an illness, while at the same time emphasising that the existential experience is not an illness (although of course, the existential experience may be a consequence of experiencing an illness). I will support my thesis by drawing on a short story by Albert Camus, "Jonas, or the Artist at Work", the fifth of the six short stories that make up the book meaningfully entitled Exile and the Kingdom: Stories [1957] (cf. Camus 2007b: 87-124). ${ }^{2}$

While reading "Jonas...", the reader becomes increasingly convinced that Gilbert Jonas, who is initially an active, creative and talented painter, will soon die prematurely. The death of the protagonist, which the reader seems to expect and almost cannot wait for, will either occur through the suicide of one suffering in silence, unhappy and desperate, or through exhaustion due to hunger and the continuous mental tension caused by obsession.

The deteriorating health of the protagonist, the increasing weakness, naïve and unrealistic optimism, self-deception, delusions, rationalisation, self-contentment and a lack of reflection are recurring elements throughout story. Could it be about depression? This is suggested by many of Jonas' symptoms, such as a loss of creative powers, weakness, a sense of worthlessness, the inability to make decisions, irritation, neglect of duties, a lack of assertiveness, apathy, feelings of tiredness, loss of energy followed by excessive drinking, indifference towards his wife, avoidance of contact with friends and family, and finally, complete isolation and fasting. However, my answer to this question is negative.

The culminating moment of the short story is preceded by the presentation of a number of details that are selected and described in a way that is meaningful and symbolic for a mental health professional: from the protagonist's childhood memories of the overprotectiveness of his divorcing parents, through examples of his wife's devotion, the constant support from his friend and his employment by his father's company, to Jonas' strong, narcissistic belief that he will achieve success (although in truth, he does not deserve it), and that he is not surprised when the world of art suddenly acknowledges him as an extraordinary painter.

Looking back at Jonas' life, it is easy to conclude that he has led a comfortable and happy life. After all, he has not encountered any difficulties, has not had to struggle with anything, nor suffered from any trauma; he has not even experienced any life-changing

2 The title refers to a metaphysical distancing that involves a separation from other people, family, friends, acquaintances and strangers, as well as from various forms of communication. This has been emphasised by, e.g. Caroline Sheaffer-Jones (cf. 2001). It should be added that the existential senses of exile and kingdom are fundamental to all six stories. 
events, serious dilemmas or trials. He completed all his undertakings without much effort, through submitting to the will of the people friendly towards him, and he has reacted to his successes dispassionately and coldly. In this manner, without effort, he graduated from university, made a true friend, and found a job; even in his marriage, he followed the initiative of Miss Louise Poulin, who subordinated her life to Jonas' passion without abandoning her plan of having a large family.

However, although allowing others to organise his life is a skill that can be viewed as Jonas' chief asset, it later becomes a serious problem. Jonas' submission to and withdrawal from the pressures of everyday life is presented by Camus through, among others, the rearrangement of each of the three modern appointed rooms within the studio apartment, which was rented for snobbish reasons (despite its many inconveniences) in an $18^{\text {th }}$ century estate. Initially, Jonas' studio is located in the big room, which however, becomes a living room in the evenings. Later on, his wife decides to move the studio into a smaller room, after which Jonas takes to painting in the bedroom; and then, the studio is moved from the bedroom into the hallway, from the hallway to the shower room, and in the end to the kitchen.

Although Jonas begins painting for entertainment, wanting to occupy his free time, and perhaps to avoid the depression caused by the monotony of everyday life, he unexpectedly becomes totally absorbed by the activity. However, Jonas does not have a clear artistic vision, or about what constitutes "his own aesthetic". He relies on intuition, and when he becomes popular as a painter, on the opinions of other people as well. His "disciples" have elaborate, "contradictory and categorical" opinions about his paintings; they demand that their "master" remain faithful to his style, and Jonas tries to meet these expectations. He is also forced to express his opinions about the paintings of his disciples. It is characteristic of him that "all [...] seemed to him equally interesting and indifferent" (Camus 2007b: 101), apart from one small exception which the reader does not come to know anything about.

Jonas considers himself a person who is content by having every moment of his life occupied. Thanks to this, he does not experience boredom, which he - one may assume - is afraid of. ${ }^{3}$ However, in rare moments of loneliness, when fatigue does not allow him to paint, he keeps dreaming about re-organising his life. He notices at this point that his relentless artistic work was a way of avoiding boredom, although he now cannot muster himself to do it. Jonas also ponders the meaning of painting and his own calling. Naively, he keeps repeating to himself that he simply likes painting. ${ }^{4}$ In one meaningful sentence, he indicates that he loves his children "as much as his painting because they alone in all the world were as alive as it was" (Camus 2007b: 112).

As Jonas is painting less, new paintings are sold less frequently. This, however, does not cause a financial problem for the family, because - according to the law of supply and demand - the market value of the rarer works increases. A mechanism takes place that is analogous to the one that occurs in many disorders: namely, the effect of the secondary morbid

3 Cf.: "In a sense, his life was very full, all his hours were occupied, and he gave thanks to the fate that spared him from boredom" (Camus 2007b: 101-102).

4 Cf.: "I love to paint," he still said to himself, and the hand holding the brush would hang at his side as he listened to a distant radio" (Camus 2007b: 113). 
gain - the increasing price of paintings (painted with equal diligence, but with more effort) reduces tension and stress, provides a short-term calm, is comforting and makes it more difficult to think about making any significant changes. Soon however, Jonas' popularity starts to fade, and nothing is able to compensate for the pain caused by criticism of his work. His mood continues to worsen: he experiences guilt, promises himself that he will start everything from the beginning (starting from tomorrow) and that he will paint again. He does not lose hope.

Nonetheless, Jonas' hope has a noticeably deeper dimension, one which indicates that it belongs to the existential sphere. Jonas, who is excessively lenient towards other people and never speaks ill of or judges anyone, says about himself, "Well, I'm not certain I exist. But one day I will, I'm sure of that" (Camus 2007b: 110). This statement occurs at a special moment, during a conversation in which the fundamental point, foreign for Jonas, may be expressed by the phrase: "to exist is to condemn". Jonas' words plainly indicate that he expects or even senses the possibility of having an existential experience. The motto "to exist is to condemn", in turn, is representative of the character of Jean-Baptiste Clamence from Camus' The Fall [1956], who is Jonas' clear opposite, and who makes this statement when judging his job (Camus 1956). When summarising his self-accusations, this character also utters the phrase "I was the lowest of the low", which allows him to move on to the plural and conclude with: "This is what we are" (Camus 1956: 140).

The next stage of the change in Jonas' behaviour is manifested as he starts to feel uncomfortable both among his acquaintances and those closest to him. As a result, he begins frequenting cafés that are not visited by his friends. He feels that alcohol provides him with the same kind of excitement as painting. ${ }^{5}$ By escaping from people, he makes new acquaintances - accidental ones, over a drink, or sometimes erotic ones. He notices his wife's suffering caused by this only after she starts asking him about another woman. He then feels shame and promises to mend his ways.

In the apartment, Jonas builds a narrow, high and deep loft at the junction where the hallways meet at a right angle. He equips it with a few basic objects, among which, however, there is no easel. It is bright everywhere in the apartment, but there, inside the loft, Jonas finds solace in the darkness. The noise of everyday life is present everywhere outside, but only muffled sounds from the toilet and the kitchen can reach the inside of the loft.

This withdrawal from life, or escape after he has allowed almost everyone who wanted to take advantage of him to do so, is not accompanied by a loss of hope in his painting. Jonas spends more and more time in the darkness of the loft, and he is convinced, in his narcissistic belief, that he will learn the secret of art. With time, he stops leaving the loft even for meals. He accumulates a supply of food, using the excuse of not wanting to bother his wife. However, he does not eat anything. He does not feel hungry. Eventually, he starts spending nights in the loft as well. ${ }^{6}$

5 Cf.: "He had discovered that alcohol gave him the same exaltation as those days of good work when he used to think of his painting with that tenderness and warmth he had never felt for anything but his children" (Camus 2007b: 115).

6 Here are three conversations from that period that Jonas has with a friend, Rateau: "What are you doing up there, Jonas?" "I'm working." "Without light?" "Yes, for the time being." (Camus 2007b: 119); "How are you?" he would say. "Couldn't be better" "Are you working?" "It amounts to the same thing" "But you have 
In the end, Jonas falls out of the loft. Many readers claim that the protagonist dies ${ }^{7}$. That is incorrect, because Jonas is only unconscious when he falls, and the summoned doctor concludes that this accident was caused by exhaustion, rather than illness. When the doctor is asked by Jonas' disbelieving wife if he is certain that Jonas will recover, the doctor replies that Jonas' condition is nothing to worry about (Camus 2007b: 122).

The doctor's diagnosis comes as a surprise, especially if the reader cannot remember other medical diagnoses of various literary characters, which serve as examples of people undergoing existential experiences. For instance, the characters from Leo Tolstoy's short stories (2009a; 2009b), which Lev Shestov (2003) refers to in his description of the characteristics of an existential experience, were not considered ill by their doctors: neither the hero of "The Diary of a Madman", nor Ivan Ilyich from the short story "The Death of Ivan Ilyich". The first short story begins with the following words: "Today I was taken to the provincial board for examination, and the opinions were divided. They debated and decided that I am not mad" (Tolstoy 2009a: 40). The second short story begins with the following dialogue: "But what exactly did he have?" "The doctors couldn't determine. That is, they did, but differently" (Tolstoy 2009b: 51).

These characters, being unable answer the question of why they feel a certain way, consider themselves as ill. ${ }^{8}$ Similarly, the protagonist of Fyodor Dostoyevsky's Notes from Underground, to which Shestov refers in many fragments concerning existential experience, begins his confession with the following words:

I am a sick man... I am a wicked man. An unattractive man. I think my liver hurts. However, I don't know a fig about my sickness, and am not sure what it is that hurts me. I am not being treated and never have been, though I respect medicine and doctors (Dostoyevsky 2004: 21).

no canvas!" "I'm working anyway." (Camus 2007b: 121); "But what's going on? You're so thin, you look like a ghost." "I've hardly eaten for a couple of days. It's nothing, I must work." "Eat first." "No, I'm not hungry" (Camus, 2007b: 121).

7 This was observed by English Showalter, Jr., who mentions Gaëtan Picon, Andre Nicolas and Dominique Aury as among those convinced of Jonas' death (Showalter 1984: 90).

8 The narrator of "The Diary of a Madman" speaks about the diagnosis in the following way: "They declared me to be subject to affects and something else of the sort, but - in my right mind; they declared it, but as for me, I know that I am mad" (Tolstoy 2009a: 40). And then, he gives the following account of the attacks he has experienced: "I tried to think about what interested me: my purchase, my wife - not only was there nothing cheerful, but it all became null. Everything was overshadowed by terror at my perishing life. I had to fall asleep. I lay down. But as soon as I lay down, I suddenly jumped up from terror. And anguish, anguish, such spiritual anguish as comes before vomiting, only spiritual. Eerie, frightening, it seems you're frightened of death, but then you recollect, you think about life, and you're frightened of your dying life" (Tolstoy 2009a: 44).

The attacks of disgust experienced by Roquentin, the protagonist of Jean-Paul Sartre's novel Nausea, are similar to the symptoms that are caused by elements of the surrounding reality (Sartre 1974). 
This character, for a change, is clearly aware of the human condition that disturbs his everyday functioning as a so-called "normal man". Based on this example, Shestov shows the reader a complete transformation caused by an existential experience. The "doubtful awakening", despite its inconveniences, places a person in a much more favourable situation than someone who is unaware and is a prisoner of delusions (Shestov 2003: 59).

From Camus' short story, it is not possible to conclude whether Jonas feels ill. Certainly however, similarly to Ivan Ilyich, he does not lose hope of returning to his old life. ${ }^{9}$ Jonas believes that his crisis would pass and that he would be able to devote himself to painting once again. It can be assumed that he wants this, because painting is a pleasurable sphere of loneliness, which hides the absurdity and explains his family, friends and the whole world to him in a simple and convenient way. In turn, the loss of this "alibi" reveals the absurdity of life, showing him that something is wrong in his life that requires remedying. On the other hand, it should be remembered that artistic creativity, thanks to its metaphysical dimension, is clearly one of the possible paths to an existential experience.

\section{IV}

It is worth asking about the identity of the doctor who firmly concluded that Jonas, after having fallen out of the loft, was not sick, even though so many of his symptoms indicated an illness. Such a diagnosis would not be made by someone from a school representing the worldview of scientism. However, a thesis can be formulated that this doctor may not only be someone who resembles Bernard Rieux, the protagonist of The Plague [1947], but it might indeed be Dr Bernard Rieux himself, who as a widower may have left Oran and begun practising in Paris. The premise for this interpretation is the fact that the same motives can be observed in various different works by Camus, e.g. The Plague mentions a press article that describes the arrest of a young man in Algiers for killing an Arab on a beach (cf. Camus 1948: 50), which is the plot of The Outsider (UK) [1942], also known as The Stranger (USA) (Camus 1946). If we make this assumption, we may be sure that Jonas was indeed entirely healthy. Rieux's role is privileged because he "[came to know] everything about life" (Camus 1948: 110); had "his own ideas of physical suffering, and [came] to acquire somewhat more imagination" (Camus 1948: 35) as he acquired clarity of vision (Camus 2000: 187). ${ }^{10}$

Accepting this hypothesis allows us to go even further and to quote statements from The Plague about illness and health that may shed light on Jonas' situation, and thus explain the sense of his existential experience. With the words of an old asthmatic patient of Doctor Rieux in mind - "But what does that mean - 'plague'? Just life, no more than that." (Camus 1948: 253).

9 Cf.: "This was [...] an hour before his death. [...]. Just then Ivan Ilyich fell through, saw light, and it was revealed to him that his life had not been what it ought, but that it could still be rectified" (Tolstoy 2009b: 95). "The reference to clarity of vision is present in the Polish version and the French original, although it has been lost in the English translation of the text."

10 The reference to clarity of vision is present in the Polish version and the French original ("Je suis dans la nuit, et j'essaie d'y voir clair", Camus 1947: 119), although it has been lost in the English translation of the text. 
Let us focus on only a few traits:

- the sense of exile: "Thus the first thing that plague brought to our town was exile" (Camus 1948: 62);

- experiencing time in an exceptional manner: "It was undoubtedly the feeling of exile that sensation of a void within which never left us, that irrational longing to hark back to the past or else to speed up the march of time, and those keen shafts of memory that stung like fire." (Camus 1948: 62);

- experiencing anxiety and the particular kind of reflection that is related to it: "And it was then that fear, and with fear serious reflection, began." (Camus 1948: 23), "Rieux felt his anxiety increasing after each visit" (Camus 1948: 32);

- attempts to deny the experienced state: “'But I feel sure it's not contagious,' he hastened to assure me" (Camus 1948: 27);

- experiencing loneliness: "An invalid needs small attentions, he likes to have something to rely on, and that's natural enough. [...] An invalid feels out of it there. Think what it must be for a dying man, trapped behind hundreds of walls all sizzling with heat, while the whole population, sitting in cafes or hanging on the telephone, is discussing shipments, bills of lading, discounts! It will then be obvious what discomfort attends death, even modern death, when it waylays you under such conditions in a dry place." (Camus 1948: 6);

- the feeling of losing the ground under one's feet, or of losing one's roots: "There lay certitude; there, in the daily round. All the rest hung on mere threads and trivial contingencies; you couldn't waste your time on it. The thing was to do your job as it should be done." (Camus 1948: 38); "So that's the idea you have of your profession?" "More or less." (Camus 1948: 108); "For the moment I know this; there are sick people and they need curing." (Camus 1948: 108);

- the issue of freedom: "They fancied themselves free, and no one will ever be free so long as there are pestilences." (Camus 1948: 35);

- the feeling of having a lack of influence on the situation: "What they're short on is imagination. Officialdom can never cope with something really catastrophic. And the remedial measures they think up are hardly adequate for a common cold. If we let them carry on like this they'll soon be dead, and so shall we." (Camus 1948: 105);

- experiencing defeat: "Only, I now can picture what this plague must mean for you." "Yes. A never ending defeat" (Camus 1948: 109).

\section{$\mathrm{V}$}

This list of traits of an existential experience is not complete; however, it is sufficient to discuss the idea of a star, which appears in the short story "Jonas..." as many as eight times. The motif of the star may be interpreted in various ways; however, in Camus' works, it connects many different aspects of his thoughts. I will only refer to selected meanings which are closer to the existential context. For Jonas, there is an association between his fate and the influence of the star: in "positive" moments, he attributes his success to it, and not to his hard work and talent. Later, the hope that his star will return keeps him alive during a continuing 
crisis. The star can therefore be understood as hope. In The Plague, we read "'So you haven't understood yet?" Rambert shrugged his shoulders almost scornfully. "Understood what?" "The plague." "Ah!” Rieux exclaimed. "No, you haven't understood that it means exactly that - the same thing over and over and over again"“ (Camus 1948: 139-140). Jonas keeps repeating that he will start everything anew. Falling out of the loft may be such a new start.

Incidentally, it is worth adding that as an editor of a series of books titled nomen omen, Hope (Espoir), Camus wrote a blurb for the cover, stating that hope is a cure for nihilism:

We are stuck in nihilism... We will not break free from it by pretending that we do not notice the evils of our times or by denying their existence. On the contrary, the only hope lies in calling them by their names and making an inventory to cure the illness... We can conclude, therefore, that the time of hope has come, even if it is a difficult hope... [translated from the Polish] (after Lottman 1993: 204).

The star that Jonas believes in is also a sign of irrationalism. In The Myth of Sisyphus [1942], Camus concludes that: "The absurd man [...] recognizes the struggle, does not absolutely scorn reason, and admits the irrational" (Camus 1991a: 37).

For Camus, the star also has a symbolic meaning with respect to beauty. In The Rebel. An Essay on Man in Revolt [1951] he wrote that:

Art, at least, teaches us that man cannot be explained by history alone and that he also finds a reason for his existence in the order of nature. For him, the great god Pan is not dead. His most instinctive act of rebellion, while it affirms the value and the dignity common to all men, obstinately claims, so as to satisfy its hunger for unity, an integral part of the reality whose name is beauty. One can reject all history and yet accept the world of the sea and the stars (Camus 1991b: 276).

What else does the star symbolise? The star may be understood as the expression of a desire for order in the world, which is a natural desire for humans. Jonas accepts this order of things. The motif of stars and using them to determine someone's place in the world also appears in other works by Camus. For instance, in the short story "The Adulterous Wife", the heroine faints due to the influence of the stars. ${ }^{11}$

\section{VI}

The star also refers to the art of navigation; as such, it is also a reference to the voyage of the biblical Jonah. Camus entitles us to a broader consideration of this topic by giving us a hint not only through the name, but also through the epigraph of the short story, which is a quotation from the biblical Jonah, who is confessing to his co-travellers that the storm

11 Cf.: "After a moment, however, it seemed to her that a kind of slow gyration was sweeping the sky above her. In the depths of the dry, cold night thousands of stars were formed unceasingly and their sparkling icicles no sooner detached than they began to slip imperceptibly toward the horizon. Janine could not tear herself away from the contemplation of these shifting fires. She turned with them, and the same stationary progression reunited her little by little with her deepest being [...]. A moment later, the whole sky stretched out above her as she lay with her back against the cold earth" (Camus 2007a: 24-25). 
threatening the ship is a response to his escaping from God's order: "Take me and throw me into the sea, and then it will calm down for you. I know it is my fault that this great storm has struck you." (Jn 1:12). Remember that Jonah found himself on board the ship because he was running away from a mission that God personally gave to him: he was to tell the citizens of Nineveh that they would be destroyed if they did not turn away from evil.

Notably, everyone on the ship, except Jonah, is struggling with the storm and throwing the unnecessary ballast overboard, which indicates that the situation is really dramatic, but through all of this Jonah is sleeping below the deck. It is only after he has been woken up and asked questions that he tells the crew to throw him into the sea. This is how his escapes from the fate, or from becoming himself.

He finds himself in the sea, where he is swallowed by a giant fish. After three days and nights spent in the stomach of the fish, it spits him out onto the land. Only after this event does Jonah carry out the mission that was given to him by God. He fulfils his calling: he warns the citizens of Nineveh about their impending doom, and they abandon their sinful way of living; thus, God spares the city. ${ }^{12}$

Jonah ordered his shipmates to throw him into the water because this proved to be necessary for saving other people. However, Jean-Baptiste Clamence from The Fall is Jonas' opposite: when witnessing a woman drowning in a canal in Amsterdam, he does not try to save her. Neither would he not do so if he found himself in such a situation again (cf. Camus 1956: 147). The symbolic meaning of water for Jonas in the Camus story is no less clear. In the countenance of his suffering wife, who has asked him about another woman, he saw the face of a drowning victim (Camus 2004: 92), ${ }^{13}$ after which, he leaves the apartment, and rain is falling at the time. He comes back with the planks from which he builds the loft. ${ }^{14}$ It is impossible not to notice the similarity between Jonas' loft and the fish that swallowed his biblical namesake.

\section{VII}

Did Jonas, who spent the last days before he fainted in the loft in isolation from the world (almost as complete as the isolation experienced by his biblical patron inside the fish), also learn from his experiences and stop running away from his calling? On the last page of

12 The change of God's decision drove him into such a mood that he started to wish himself dead. He uttered words similar to those of Elijah who was experiencing weakness: "So now, Yahweh, please take my life, for I might as well be dead as go on living" (Jn 4:3). It can be assumed that he regretted fulfilling his calling, in that he helped to save the sinners. Later, while pitying a plant (a Ricinus), which died because of a worm and that could not give him shade in the desert, he once again expressed the wish for death saying: "I might as well be dead as go on living" (Jn 4:8). These events were a lesson for Jonah: just as Jonah was not indifferent to the fate of the plant, so was God not indifferent to the citizens of Nineveh, whom he simply could not come to destroy.

13 The reference to a drowning victim is present in the Polish version and the French original, although it has been lost in the English translation of the short story.

14 In other short stories from the volume Exile and the Kingdom, there are analogous objects with philosophical, symbolic meanings, e.g. a ledge, balcony, plateau, etc. 
this story of the painter, the reader learns that in these extremely uncomfortable conditions, completely unfit for painting with no light or easel, Jonas has painted a picture after his long period of unproductiveness. This painting, which might have been a breakthrough work for Jonas, is found in the loft (after the painter has fainted) by his loyal friend, Rateau. The central part consists of a white surface, where there is one word written in small black letters in such a way that it could be read either as solitaire (solitary) or as solidaire (solidary). Some readers claim that the canvas found in the loft is blank, indicating that the painter was not able to carry out his intention of painting a picture. ${ }^{15}$ However, covering the canvas in white, a very meaningful colour, does not mean that the canvas was empty. ${ }^{16}$

The assumption that the "mistake" in the word written on the white background is a manifestation of "a painter's variant of developing word salad" (schizophasia), or a writing disorder that is connected with a psychosomatic state or a dyslexic's mistake, could only be made if we negate the doctor's opinion, who has claimed that Jonas is healthy, and if we separate ourselves from the context of Camus' philosophy. Jonas' experience was, most probably, an existential experience, one which awakened his awareness, and the painting consequently became an expression of this experience.

\section{VIII}

According to Camus, the existential experience is the experiencing of the absurdity of being shaken out of a previous slumber. In his The Myth of Sisyphus, the philosopher mentions many situations that can enable a human to experience this absurdity. These are moments in which the sham nature of the order and purposefulness of everything is revealed. The philosopher writes: "the chain of daily gestures is broken, in which the heart vainly seeks the link that will connect it again" (Camus 1991a: 12). The moment of this breakthrough for Jonas is his wife's remark about one of his lady friends. Jonas is interrupted in his short-term actions aimed at avoiding awareness of what he and the surrounding world are like. These actions are pushing him further away and are an escape from his purpose: the purpose of a human to fulfil himself as an existence. This is same escape as the one made by his biblical patron, who boards a ship and sails in the direction opposite to the one that God has directly indicated to him.

In the painting, the artist-painter has managed to express something that the eyes cannot see; something that philosophers have difficulty in putting into words. He shows that he could not find a "term", and that he did not have a "theory", but also that "there are two sides to

15 This is an opinion of, for instance, Wojciech Natanson, who also adds a rather inaccurate opinion in Littera nocet, littera docet (cf. Natanson 1980: 67).

16 The small room in which Jonas spent time with his paintings before fainting refers to his opposite, Jean-Baptiste Clamence from The Fall, who confessed that in his small room, in which he lay when sick, he kept van Eyck's painting "The Just Judges" (cf. Camus 1956: 128). This concerns the bottom left panel of The Ghent Altarpiece from St Bavo's Cathedral in Ghent, created by Hubert and Jan van Eyck, which was stolen in 1934 and has never been found. Currently, a copy of the painting is there. One of the paintings depicts John the Baptist (Jean-Baptiste). 
the same thing", ${ }^{17}$ such as a figure and its background or white and black - that which can be expressed through a combination of fine arts and the art of the word. The painter shows the double nature of human existence: solitude and community. The experience of loneliness and the experience of a common fate complement one another and create unity. Jonas has discovered for himself that he had to be both solitary and in solidarity (as the attempt to choose only one of these polar opposites ended in disaster).

This constitutes a constant motif in Camus' philosophy of existence: solitude is as essential for a human being as solidarity; and it is while rebelling that someone discovers that he or she is not alone and is truly human: "I rebel - therefore we exist" (Camus 1991b: 30).

It seems that this optimistic interpretation of Camus' work is encouraged by the author himself and is indicated by his development, which progresses from rebellion to hope, from The Myth of Sisyphus [1942], The Stranger [1942], and Caligula [1938] to The Rebel [1951] and The Plague [1947] (cf. Camus 1991a; 1946; 1987; 1991b; 1948), and that shows a dialectic of absurdity and rebellion. ${ }^{18}$ Whether Jonas will be able to persevere in clear awareness, or return to a false form, is another issue.

\section{IX}

It is also worth looking at Jonas' situation through the prism added by the subtitle: "The Artist at Work". As Jonas' state progresses it is more and more difficult for him to find a place and a time to work, or the strength to devote himself to the act of creating. The narrative is constructed in such a manner that we do not know anything about his inner life; only his behaviour is shown to the reader. However, the consequences of his actions allow us to make assumptions about what the character has experienced. The characteristics of the possible mental states of the protagonist-artist can be found in the chapter "Rebellion and Art" of the essay The Rebel. An Essay on Man in Revolt. The chapter discusses an artist-writer, but it may be assumed that it is also about Jonas, if he has managed to keep the awareness of his existential experience, or the awareness of the fact that artistic creation is a form of rebellion against the world as it is and an attempt at correcting it. This is what, in some manner, Rieux did as well in The Plague. Camus wrote that:

It is therefore justifiable to say that man has an idea of a better world than this. But better does not mean different, it means unified. This passion which lifts the mind above the commonplaces of a dispersed world, from which it nevertheless cannot free itself, is the passion for unity. It does not result in mediocre efforts to escape, however, but in the most obstinate demands. Religion or crime, every human endeavour in fact, finally obeys this unreasonable desire and claims to give life a form it does not have. The same impulse, which can lead to the adoration of the heavens or

17 This is also a title of one of Camus' essays, Betwixt and Between, also translated as The Wrong Side and the Right Side.

18 It can be added that Clamence from The Fall sheds more light on the process. His transformation goes in the opposite direction: he abandons solidarity for solitude, and from that moment he does not find peace: "I agreed to duality instead of worrying about it" [translated from the Polish] (Camus 2000c: 410). 
the destruction of man, also leads to creative literature, which derives its serious content from this source (Camus 1991b: 247).

Furthermore, Camus wrote that for artists, the issue is not so much distancing themselves from the world as it is suffering (with the exception of rare moments of true unity with the world) from not feeling connected enough with the world and not possessing the world enough (Camus 1991b: 245).

\section{$\mathrm{X}$}

To sum up, it may be concluded that existential experience is like an illness. It reveals the value of life, the true human condition and that human existence is unavoidably connected with chance, suffering, fighting, guilt and death, and that it is only by experiencing one's own reality with full awareness and struggling that a human being finds out who he or she is. ${ }^{19}$ However, although the existential experience resembles an illness, it is not one, as it reveals the human existence in its full capabilities, rather than revealing it through its limitations, ailments and weaknesses.

\section{REFERENCES}

Camus, Albert. 1946. The Stranger, transl. Stuart Gilbert, New York: Random House.

Camus, Albert. 1947. La Peste, Paris: Editions Gallimard.

Camus, Albert. 1948. The Plague, transl. Stuart Gilbert, New York: Random House.

Camus, Albert. 1956. The Fall, transl. Justine O'Brien, New York: Random House.

Camus, Albert. 1987. Kaligula, transl. Wojciech Natanson, in: Dramaty, Kraków: Wydawnictwo Literackie, pp. 11-81.

Camus, Albert. 1991a. The Myth of Sisyphus and Other Essays, transl. Justine O'Brien, New York: Random House.

Camus, Albert. 1991b. The Rebel: An Essay on Man in Revolt, transl. Anthony Bower, New York: Random House.

Camus, Albert 2000. Dżuma, transl. Joanna Guze, in: Cztery powieści. Obcy, Dżuma, Upadek, Pierwszy człowiek, Warszawa: Świat Książki, pp. 91-327.

Camus, Albert. 2004. Jonas, albo artysta przy pracy, in: Wygnanie i królestwo, transl. Joanna Guze, Kraków: Wydawnictwo Zielona Sowa, pp. 69-96.

Camus, Albert. 2007a. Adulterous Wife, in: Exile and the Kingdom: Stories, transl. Carol Cosman, New York: Vintage International, pp. 3-27.

19 I only mention here some limited situations. Their extensive interpretation would be very interesting for the purpose of the discussed topic, as Karl Jaspers, who developed the concept, was both a philosopher and a psychiatrist (cf. Jaspers 1954). 
Camus, Albert 2007b. Jonas, or The Artist at Work, in: Exile and the Kingdom: Stories, transl. Carol Cosman, New York: Vintage International, pp. 87-124.

Dostoyevsky, Fyodor. 2004. Notes from Underground, transl. Richard Pevear and Larissa Volokhonsky, New York: Everyman's Library, Penguin Random House.

Jaspers, Karl. 1954. Psychologie der Weltanschauungen, Berlin - Gottingen - Heidelberg: Springer-Verlag.

Lottman, Herbert R. 1993. Albert Camus. Biografia, transl. Irena Szymańska, Warszawa: Oficyna Wydawnicza Szczepan Szymański.

Mounier, Emmanuel. 1964. Wprowadzenie do egzystencjalizmów oraz wybór innych prac, transl. Ewa Krasnowolska, Kraków: Znak.

Natanson, Wojciech. 1980. Szczęście Syzyfa, Kraków: Wydawnictwo Literackie.

Piecuch, Czesława. 1998. Doświadczenie egzystencjalne w perspektywie metafizycznej, Kraków: Wydawnictwo Akademii Ekonomicznej.

Piecuch, Czesława. 2011. Metafizyka egzystencjalna Karla Jaspersa, Kraków: TAiWPN Universitas.

Sartre, Jean-Paul. 1974. Mdłości, Warszawa: Państwowy Instytut Wydawniczy.

Sheaffer-Jones, Caroline. 2001. The undecipherable painting: Camus' 'Jonas ou l'artiste au travail, "Mots Pluriels", http://motspluriels.arts.uwa.edu.au/MP1701csj.html [18.06.2017].

Showalter, English. 1984. A Reading of Camus's Exile and the Kingdom, Ohio: Ohio State University Press.

Sontag, Susan. 1999. Choroba jako metafora. AIDS i jego metafory, transl. Jarosław Anders, Warszawa: Państwowy Instytut Wydawniczy.

Shestov, Lev. 2003. Na szalach Hioba. Duchowe wędrówki, transl. Janusz Chmielewski, Warszawa: Fundacja Aletheia.

The Book of Jonah, http://www.catholic.org/bible/book.php?id=39 [19.07.2017].

Todd, Olivier. 2009. Albert Camus. Biografia, transl. Jan Kortas, Warszawa: W.A.B.

Tolstoy, Leo. 2009a. The Diary of a Madman, in: The Death of Ivan Ilyich and Other Stories, transl. Richard Pevear and Larissa Volokhonsky, New York: Alfred A. Knopf, pp. 40-50.

Tolstoy, Leo. 2009b. The Death of Ivan Ilyich, in: The Death of Ivan Ilyich and Other Stories, transl. Richard Pevear and Larissa Volokhonsky, New York: Alfred A. Knopf, pp. 51-96.

Warnock, Mary. 2005. Egzystencjalizm, transl. Monika Michowicz, Warszawa: Prószyński i S-ka.

Wilson, Colin. 1992. Outsider, transl. Maria Traczewska, Poznań: Wydawnictwo Rebis.

Wójs, Paweł. 2013. Rozum w filozofii egzystencji, Kraków: TAiWPN Universitas.

Wójs, Paweł. 2017. Filozofowie egzystencji, in: Marek Błaszczyk (ed.), Oblicza egzystencjalizmu, Kraków: Studio Grafpa i Autorzy, pp. 17-30.

DOŚWIADCZENIE EGZYSTENCJALNE JAK CHOROBA.

STUDIUM PRZYPADKU GILBERTA JONASA

W dziełach filozofów egzystencji nierzadko pojawia się problematyka choroby i zdrowia w kontekście dociekań dotyczących trudnego do opisu doświadczenia egzystencjalnego. Teza artykułu brzmi: jedną ze strategii wybieranych przez autorów, którzy dążą do scharakteryzowania doświadczenia egzystencjalnego, jest przedstawianie go w kontekście choroby. Strategia ta polega przede wszystkim na ukazywaniu podobieństwa 


\section{PAWEŁ WÓJS}

doświadczenia egzystencjalnego i choroby, z jednoczesnym podkreślaniem, że doświadczenie egzystencjalne chorobą nie jest (oczywiście nie wyklucza się tutaj sytuacji, w której doświadczenie egzystencjalne stanowi następstwo doświadczenia choroby). Wsparcie dla postawionej tezy znajduję w dorobku Alberta Camusa, Lwa Szestowa i innych filozofów egzystencji oraz w twórczości literackiej. W artykule przeprowadzam interpretację opowiadania Camusa Jonas, albo artysta przy pracy; omawiam podstawowe cechy doświadczenia egzystencjalnego, skupiając się na tych, które są pokrewne objawom chorób; formułuję uwagi, które stanowią uogólnienie dotyczące doświadczenia egzystencjalnego.

Słowa kluczowe: choroba, zaburzenie, doświadczenie egzystencjalne, egzystencjalizm, filozofia egzystencji 